\title{
THE ANALYSIS OF MARKET PARTICIPANTS MANAGING THE REVERSE LOGISTICS FLOWS AND BUSINESS OPERATIONS
}

\author{
Veljko M. Mijušković ${ }^{25}$ \& Iva Vuksanović Herceg ${ }^{26}$
}

\author{
UDC / UDK: 65.12.34:005 \\ JEL classification / JEL klasifikacija: M00 \\ DOI: https://doi.org/10.22598/pi-be/2019.13.1.121 \\ Review / Pregledni rad \\ Received / Primljeno: March 25, 2019 / 25. ožujka 2019. \\ Accepted for publishing / Prihvaćeno za tisak: May 6, 2019 / 6. svibnja 2019.
}

\begin{abstract}
Summary
While segregating the direct and reverse logistics flows, due to the complexity of the returns process management, there have emerged specific market players unique only for these flows. Regarding the organizational aspect, these entities can be formed by the participants of the direct flows, but can also be engaged as specialized external aid. The analyses carried out in practice concerning this topic show that the biggest number of entities involved in managing the reverse logistics processes are within the category of specialized business subjects, which only perform this type of work and which are independent from the actors of regular flows. The subject of this paper is to analyse in depth the volume and importance of reverse logistics flows, focusing on the specifics and types of entities specialized in managing these flows, such as centralized return centres, $3 P L$ and 4PL providers for reverse flows, as well as various business entities of the secondary market. The aim of the paper is to indicate the complexity of tasks performed by specialized entities involved in the reverse logistics process, their scarcity in numbers on a global scale and thus the huge unexploited business potential lying in this market segment. That is a unique chance not only for regional, but also global business milieu.

Key words: Reverse logistics volume, reverse logistics importance, centralized return centres, $3 P L$ and $4 P L$ providers, secondary markets.
\end{abstract}

\footnotetext{
${ }^{25}$ Veljko M. Mijušković, Ph.D., Assistant Professor, Belgrade University, Faculty of Economics, Serbia, E-mail: mijuskovic@ekof.bg.ac.rs

${ }^{26}$ Iva Vuksanović Herceg, Ph.D., Assistant Professor, Belgrade University, Faculty of Economics, Serbia, E-mail: ivav@ekof.bg.ac.rs
} 


\section{INTRODUCTION}

The segregation of direct and reverse logistics flows, necessary due to the complexity of the returns realization, creates a need for specific market players which are unique for these flows. Contemplating the issue of organization, the mentioned entities can be formed by participants of the direct flows, but can also be engaged as specialized, external aid (Dudin et al., 2017). The practical analyses concerning this issue have shown that the greatest number of entities involved in the returns process are mainly in the category of specialized performers, which only do that type of job and which are independent from the entities of the regular flows. That only confirms once more the complexity of the realization of activities of the returns process. Of course, there are those entities of the reverse flows which are traditionally organized by the regular flow members. Mostly, such participants are a minority (Trebilcock, 2001).

Besides the organizational specifics, the entities engaged within the reverse logistics process are characterized by a significant number of other peculiarities, which are presented within the following analysis. Continuing we shall revise in detail the volume and importance of the reverse logistics process, followed by an analysis of the most important market players of this process: Centralized return centres, 3PL and 4PL providers and different participants of the secondary market.

\section{THE VOLUME ESTIMATE AND IMPORTANCE OF THE REVERSE LOGISTICS ACTIVITIES}

The increase of importance of reverse logistics for the success of company business, but also the economy as a whole, is the basic reason for the rise of interest of different market players and entities to manage the needed skills for the efficient organization of the reverse flow of goods (Wiggins, 2019). Precise data and practical experience corroborate that this is not just a mere business, nor scientific trend. The mentioned data refer to the volume of reverse logistics activities, expressed in economically measurable categories, by different quantitative data and indicators, on a differentiated level of analysis. Also, there is empirically confirmed knowledge concerning the importance of reverse logistics, where it is possible to identify a great number of reasons why this set of activities has a strategic character for companies which adequately use it.

Determining the volume, i.e. the size of reverse logistics flows is not at all an easy task. One of the main reasons of such complexity is the significant variation of volume operations and influence of reverse logistics depending on the precise industry for which the analysis is performed, or a position of an individual company in a certain supply chain (Paula et al., 2019). Unfortunately, the situation is additionally complicated by the fact that many companies still weakly identify, follow and control the activities of reverse logistics, and therefore do not know the precise volume of action which is being effectuated (De Brito and Dekker, 2004). 
However, it is generally known that the volume of reverse logistics activities in the economy as a whole is vast and it is recording an uprising trend, so the analysis of this issue can be started on a macro level (Govidan et al., 2019). For that purpose, as a rough approximation of the global state, we can use the only wider available data which concern the size of reverse logistics and which refer to the market of USA. The volume of reverse logistics activities in this case is expressed through a percentage of cost participation in total logistics costs, in GDP, as well as a percentage estimate of the total quantity of returned goods. It is a general estimate that the total logistics costs in the USA are around $10,7 \%$ of the total costs of the national economy, while the reverse logistics costs participate in total logistics costs at around $4 \%$, i.e. 47 billion dollars. Comparing that with the total country GDP, we come to the data that the costs of reverse logistics account for $1 \%$ of the country`s GDP. Finally, the estimate of the Center for logistics management of the University of Nevada, USA, shows that between $6 \%$ and $8 \%$ of all produced goods in some moment is being placed back into the reverse logistics channel. (Hall et al., 2013). Based only on stated data it is clear that the realization of the reverse logistics activities certainly represents a serious area of consideration.

Regarding the individual areas of economy, i.e. particular industries, it can be stated that the volume of reverse logistics activities significantly varies, so their importance is consequently different. So, in some industries, the reverse logistics has a marginal role, while in some it is of vital importance. It is a general rule that companies of high product value or which have a high rate of return, invest most efforts to improve the reverse processes. Originating from the division of goods in the reverse logistics channel onto products and packaging, the biggest product return can be located with the final consumer. Estimates are that the general return percentage of all kinds of goods, with different retailer categories is around 6\% (Haas et al., 2003). The return percentages for chosen industries are given within the following Table 1:

Table 1. Return percentages for chosen industries/types of goods

\begin{tabular}{|l|l|}
\hline Industry & \% of return \\
\hline Daily/weekly newspaper & $50 \%$ \\
\hline Book publishers & $20-30 \%$ \\
\hline Book distributors & $10-20 \%$ \\
\hline Catalogue retail & $18-35 \%$ \\
\hline Electronic distributors & $10-12 \%$ \\
\hline Computer producers & $10-20 \%$ \\
\hline Printer producers & $4-8 \%$ \\
\hline Fast moving consumer goods sales & $4-15 \%$ \\
\hline Car-part sellers & $4-6 \%$ \\
\hline House appliances & $4-5 \%$ \\
\hline Domestic chemistry & $2-3 \%$ \\
\hline
\end{tabular}

Source: Roggers, D., Tibben-Lembke, R. (1999), pp. 145-149. 
Analysing the data given within Table 1 a clear disproportion can be seen between the rate of return which is determined by the type of job and kind of products which are dominant within particular industries. Based on these data it can also be concluded that some of the given industries regard the management of reverse flows as an activity of primary value (for example, the importance of the daily newspaper return).

Determining the volume of activities of reverse logistics at the level of an individual company represents the most demanding task, especially bearing in mind the fact that a great number of companies does not identify in the best possible way, or does not identify at all which segments and activities within its business fall into this category (Govidan et al., 2019). Also, as is the case with the entire branch and/or industry, the type of product and precise business significantly determine the size of the reverse logistics flows. Therefore, for this level of consideration it would be utterly ungrateful, but also methodologically incorrect to determine with precision the volume of the reverse logistics activities.

However, bearing in mind the fact that reverse logistics activities are becoming more and more the means of competitive fight between market participants, certain tools have been developed to aid an individual company which wishes to efficiently manage them. In order to do so, the company must first determine the size of carried out reverse logistics activities. For that purpose, an equation of return logistics costs can be used, where the volume of reverse logistics activities is calculated as a sum of key cost components or categories connected to creation, management, processing and final disposal of returned goods. The equation of return logistics costs has the following form: (Blackburn et al., 2004)

\section{Total costs of return logistics $=$ processing costs + logistics costs + exchange costs + resources depreciation costs}

Analysing every particular component of the stated equation a more detailed insight into the elements it contains is obtained. Thus, processing costs refer to all costs connected to managing returns. For example, the returns process can be initiated by the approval of the return by the person engaged within the company call centre. After that follows the return of the goods onto the warehouse and its modification/refurbishment. The logistics costs include all costs of manipulation of the returned goods, as well as costs of sending the replacement unit. Under this category we include all costs of transport, procurement, warehouse and supply management which are not included within processing costs. The majority of the returned goods demand issuing a replacement in the form of a same or a similar product, which leads to the creation of exchange costs connected with this process. Finally, all returned goods have some degree of residual value, even in the case of recycling or waste management. If the returned goods are not managed efficiently enough, their financial value can be lost in time, or at least significantly reduced (Blackburn et al., 2004).

Within the following Table 2 there is an indicated influence of particular components of the equation of return logistics costs onto company savings, based on empirical evidence (Mukhopadhyay \& Setaputra, 2006). 
Table 2. The influence of particular components of the equation of return logistics costs onto company savings

\begin{tabular}{|l|l|}
\hline Costs component & $\begin{array}{l}\text { Potential range of savings- } \\
\text { from } \$ \text { (very small savings) to } \$ \$ \$ \$ \\
\text { (extremely significant savings) }\end{array}$ \\
\hline Processing costs & $\$-\$ \$$ \\
\hline Logistics costs & $\$-\$ \$ \$$ \\
\hline Exchange costs & $\$ \$ \$-\$ \$ \$ \$$ \\
\hline Resource depreciation costs & $\$ \$-\$ \$ \$ \$$
\end{tabular}

Source: Mukhopadhyay, S., Setaputra, R. (2006), pp. 716-730.

Having analysed the volume of reverse logistics flows, what remains is to indicate their importance, in order for so many market participants to be interested into performing them in practice. The most relevant reasons of strategic importance of the reverse logistics flows, also identified within a practical empirical research, can be summed up within Table 3 (Stock et al., 2006):

Table 3. Elements of strategic importance of reverse logistics flows

\begin{tabular}{|l|l|}
\hline Element of strategic importance & $\begin{array}{l}\text { Percentage of respondents } \\
\text { consent to the justification } \\
\text { of that element }\end{array}$ \\
\hline Reasons of competitive nature & $65,2 \%$ \\
\hline Lowering the supply volume within the chain & $33,4 \%$ \\
\hline Legal issues concerning product disposal & $28,9 \%$ \\
\hline The return of the residual good value & $27,5 \%$ \\
\hline The return of the very good & $26,5 \%$ \\
\hline Protection of supply chain profit margins & $18,4 \%$ \\
\hline
\end{tabular}

Source: Stock, J., Speh, T., Shear, H. (2006), pp. 57-62.

Summing up the initial analysis concerning the volume and importance of reverse logistics flows it can be concluded that there is a great number of reasons why managing the reverse logistics flows is considered relevant in the contemporary struggle of various market players. Since this is a rising trend, it is legitimate to consider that the number and type of these entities shall only continue to grow in the future. Following, three main market player categories of reverse logistics flows are analysed in detail.

\section{THE ROLE OF CENTRALIZED RETURN CENTRES}

The centralized return centres represent entities devoted to quick and efficient processing and management of returned goods. Although in the developed western economies these centres have been in use for a number of years, only recently have they additionally gained importance and popularity. The reason for this lies in the fact that 
more and more retailers and producers are deciding to dedicate specialized premises and work force exclusively for management and processing of returns (Fleischmann et al., 1997). Out of the stated it can be concluded that the centralized return centres precisely represent those rare entities which are dominantly, i.e. in the majority of cases organized by the same market participants as the regular flows. Within the centralized system, all goods in the reverse logistics channel are gathered at one point, at which they are sorted, processed and then sent off to the following destination. In that manner, the greatest possible quantities of returned goods are created and the need to be replace on the market again, opening up the space for serious potential earnings. The increase of earnings within these centres has been enabled due to the engagement of specialized personnel for sorting, with the expertise within the area which significantly facilitates the placement of every product towards a certain destination (Fleischmann et al., 1997).

Generally seen, the centralized return centres function through a set of activities grouped in several standardized steps. At the beginning, the retail object sends the product back to one or a greater number of centralized centres. If it is a great retailer, national or a multinational company, there shall probably be more of these centres. For example, the American retail chain Kmart has four, while its competitor Sears has three centralized return centres (Roggers and Tibben-Lembke, 1999). After the returned goods have been accumulated in a certain measure, the next step is their sorting and processing, which are considered very important steps of the flow. Within it, the employees make decisions in which state it is possible to sell a returned product or if that is not an option, how to most easily send it to waste. Obviously, the selection of the best channel for goods placements is of critical importance for the maximization of income within the reverse logistics flow. Finally, the decision about the suitable mode of treating the good the centralized centers make based on guidelines which have been set by the retailer or producer. Figure 1 shows the graphical illustration of the mentioned activities:

Figure 1. Activities carried out within Centralized Return Centres

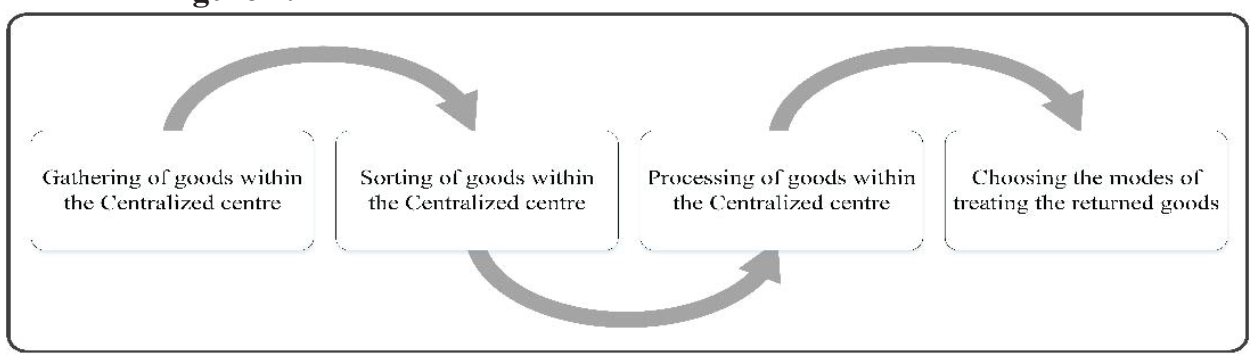

Source: Roggers, D., Tibben-Lembke, R. (1999), p. 51.

The forming of the centralized return centres, as a specific entity of the reverse logistics process, brings numerous benefits for participants which organize them most often, i.e. for retailers or producers. The main benefits of establishing such centres are given within Table 4: 
Table 4. The main benefits of establishing the centralized return centres

\begin{tabular}{|l|}
\hline The consistency about the decisions on treating the returned goods \\
\hline The rationality in using space \\
\hline Workforce cost savings \\
\hline The decrease of transport costs as a part of the logistics flow due to the consolidation \\
\hline Improving customer service \\
\hline Time savings needed for the realization of the chosen option of product return \\
\hline The positive influence on generated profit \\
\hline
\end{tabular}

Source: Roggers, D., Tibben-Lembke, R. (1999), pp. 52-54

The analysis of particular advantages points out several relevant moments. First of all, sending all returned goods through the centralized return centres results in increasing the concordance of decisions concerning their treating. Since in that manner, the process is standardized, the errors are identified and avoided more easily. The quality of processing returns is generally improved by passing onto the system of centralized return flows (Baumgarten et al., 2004).

Second, the retailers most often possess a limited space within their objects which can be dedicated to returned goods. Usually, the best exposed parts are reserved for new and returned products which sell quickly, and not for the returns which nobody wants. Because of that, forming of the centralized return centres, where precise sorting and processing of products is performed, brings as one of the main benefits for retail the rational usage of their space, since only those products which can be quickly placed on the buying market shall be returned (Dowlatshahi, 2010).

Third, centralizing the return centres one more advantage for the retailer is the minimization of labour force costs in order for the return to be processed. Namely, once adequately trained, the employee of the centralized centre can perform more activities in a shorter time period, then the employee in retail, which realizes both regular activities as well as the coordination of the reverse logistics flows (Dowlatshahi, 2010).

Forth, due to consolidation, transport costs within the reverse logistics flow decrease. Within the centralized model, using the mixed cargo of different suppliers, the usage of mutual pallets increases and the usage of individual package decreases, which brings to the unification of shipments and the consequential reduction of transport costs. However, it must be remembered that the centralized system of return can act completely opposite, i.e. increase the costs of manipulation and transport. That happens because all products, i.e. goods get to be transported from their retail locations, regardless of their distance to the centralized centre.

Estimating the fact that a legitimate and often return option is waste disposal, its transport up to the centralized centre facility in order to be set aside as waste afterwards exclusively increases costs, without any positive influence onto the income. However, the positive effects of implementation of the centralized return centres, expressed in the 
general costs savings, shorter time needed for the treating of returned products as well as the increased income, more than compensate the occurred transport costs for those goods which would be set as waste upon the finishing of the returns process (Haas et al., 2003).

Fifth, regarding from the perspective of the producer, the centralized return centre can improve the customer service. That can be seen in the speeding up of certain administrative procedures, setting the paper work in order, especially the one connected to the issuing of the returns permit, as well as offering relevant information for the management. Due to the consolidation of the returns, the producer can easily become aware of trends connected to the returned goods. Also, the adequate management of the return flows can be a good strategy for retaining the clients' loyalty. The mentioned loyalty is achieved by quicker processing of the transaction and giving credit to the clients. Finally, establishing the return centres is also a proof of the dedication for the incorporation of the returns management into the general strategic company orientation, which is additionally positively valued by the client (Hall et. al., 2013).

Sixth, the introduction of the centralized return centres speeds up the flow within the reverse channel. Before establishing such a system, retailers would accumulate the returned goods within objects, and then they would send them back to the producers in uneven, unorganized and bulk tours. Since the returned goods were not the first priority of the retail object or the distribution centre, they would usually pile up. The explained inefficient management of the returned goods would leave to the loss of their value and to physical damaging. For products such as personal computers, such situation is defeating, since the goods loose value during every day that they are not used (Hall et. al., 2013).

Finally, the formation of the centralized return centres has an evident positive influence onto the realized profit within the developed western economies. According to the research carried out concerning this topic, it has been proven that there is a bigger positive influence onto the achieved profit by the centralized return centres which have not been outsourced, i.e. organized by the same entities as well as the regular product flows (Roggers and Tibben-Lembke, 1999). Returning to the beginning of the analysis, the conclusion is that this is one of the main reasons why these entities are better to be organized by conventional participants, then to be realized by specialized performers.

\section{EXTERNAL PROVIDERS AS SPECIALIZED ENTITIES OF THE REVERSE LOGISTICS FLOWS}

The conventional participants within the supply chain, as has already been expressed, often do not have the needed level of expertise in order to be actively involved within the process of product returns, which is by itself, very specific. Even in the case of previously analysed centralized return centres and their coordination by participants from regular goods flows, the locations and labour force engaged within them is separated from the conventional flows. In those circumstances, the external providers, which have a more and more significant role when it comes to outsourcing the most different activities of 
logistics management, most often assume the role of organizer and activator of the reverse flows. A very special place within that process is dedicated to 3PL and 4PL providers.

3PL providers represent companies which offer multiple logistics services to clients. The concept of 3PL providing has been developed during the 80 -ies of the XX century, by introducing deregulation into the sphere of truck transport within USA. That enabled companies which up to that moment performed other logistics functions (for example warehouse management or supply management) to enter the sphere of transport and thus enrich their package offer. Today, it is also a custom for the providers to perform the mixing, i.e. combining the services which form their package offer. These companies facilitate the product flows, from the supplier of raw materials to producers and further on the distributors, retail and final clients, but also in the reverse order (Bianchini, 2018).

Services offered by 3PL providers include transport, warehousing, supply management, goods reloading and similar. Often, the unification of the system and the service scope enables providers to fulfil useful functions, such as fitting in with the regulation within the area or determining the total costs of delivered goods for sale (Hertz and Alfredsson, 2003). Since the beginning of the XXI century till now, almost $2 / 3$ of companies from the list Fortune 500 depend on some sort of 3PL support within the supply chains, thus increasing the income of these providers in the double amount compared to the last decade of the XX century (Trebilcock, 2002). In practice, the companies which are decision makers about engaging 3PL providers most often decide to outsource entire functions, rather than partial activities.

The increase of importance of the reverse logistics flows has led to the appearance of 3PL providers which exclusively process the returns of goods. Among numerous companies of this type there are most different mode of offer. Some 3PL providers are connected to reverse logistics, offer only the services of physical organization and returns realization. These are the old, traditional 3PL providers such as GENCO, USF Processors, Universal Solutions and similar companies, who have been processing returns for years for the pharmaceutical, cosmetics, clothing and electronic industry (Lai, 2004).

The second option of providers are those with the combined offer, which besides the physical services in the real world and time, offer the technological and service platform for managing the return flows in a form of specialized software. In this category we can include companies such as Newgistics, ReturnBuy and similar.

Finally, there are those providers, such as Return Exchange, which do not offer at all the service of physical nature, but exclusively offer technological and software solutions as a support for the realization of the return flows (Meade and Sarkis, 2002). Based on the stated categorization, and bearing in mind that outsourcing most often assumes the integration of the entire function, it is logical to conclude that it is best for the provider to offer integral solutions, both regarding the technical and software support, as well as precise realization. In that manner the process is unified, and the costs intended for these purposes are decreased, since it is not needed to engage several 3PL providers, but only one.

The basic shortcoming of engaging the 3PL provider is within the realization of the logistics flows, and is connected basically to the shortcomings of the 3PL category. 
That means the functional role of these companies is very limited. Namely, even if they offer unified service, 3PL providers dominantly focus on the function, rather than the way how to outsource a certain process. For example, these providers can specialize in transport, but are no longer able to master the entire process of transport management. Due to that reason, the leading edge is passed on to 4PL providers (Perotti et al.,2012).

The concept of 4PL providers has first been defined in 1996 by the consultancy company Accenture, as a way of using this type of company in order to integrate and manage the company logistics resources. 4PL providers usually do not have their own funds, i.e. business resources, but rather specialize in managing the resources of others. In order to achieve that, 4PL logistics providers combine the skills of process, technology and management (Dyczkowska, 2018). These providers are neutral and can manage the entire logistics process regardless of the intermediaries used within the processtransporters, warehouses and similar. Consequently, 4PL providers have become a logical alternative to outsourcing business processes, offering visibility and integration for a greater number of participants within the supply chain. Those companies which use the services of 4PL providers can without problems focus on own key competences and resources, such as supplies or employees (Mukhopadhyay and Setaputra, 2006). 4PL providers are treated as a strategic partner and an integrating factor within the supply chain, which manages resources, abilities and technology of own organization with the complementary provider elements of other services, in order to deliver comprehensive solutions within the supply chain.

Differing from the usage of 3PL providers in the realization of the reverse logistics flows, the involvement of 4PL providers in this process is still of pioneer nature. It is possible to identify three models of organization of 4PL providers in the function of return flows. The mentioned models are jointly explained within Table 5:

Table 5. Models of 4PL providers in the organization of the reverse logistics process

\begin{tabular}{|l|l|}
\hline 4PL Model & Model explanation \\
\hline $\begin{array}{l}\text { The leading logistics } \\
\text { provider }\end{array}$ & $\begin{array}{l}\text { The 4PL provider acts as an in-house organizer of the } \\
\text { process of reverse logistics. It can, but it need not take } \\
\text { on the role in the selection of the 3PL partner. Its basic } \\
\text { obligation is an efficient and effective process } \\
\text { organization and the monitoring of all participants. }\end{array}$ \\
\hline Solution integrator & $\begin{array}{l}\text { 4PL provider acts as an integrator of different 3PL } \\
\text { partners engaged within the returns process as well as } \\
\text { their coordinator in the name of the client. }\end{array}$ \\
\hline Industrial innovator & $\begin{array}{l}\text { 4PL provider uses the expertise and resources connected } \\
\text { to return flows in order to create a solution not for any } \\
\text { specific client, but for a greater number of potential } \\
\text { clients which belong to a certain industry. }\end{array}$ \\
\hline
\end{tabular}

Source: Mukhopadhyay, S., Setaputra, R. (2006), pp. 716-730 
Based on presented model, the conclusion is that the degree of involvement i.e. connection of the 4PL provider to a particular client is lower and lower going from the first until the third solution. Which option shall be chosen is decided by the precise situation and company-client thoughts which initiate the provider engagement. As an illustration, Figure 2 shows the graphic review of the model 2, i.e. the role of 4PL provider as a solution integrator.

Figure 2. 4PL provider as a solution integrator

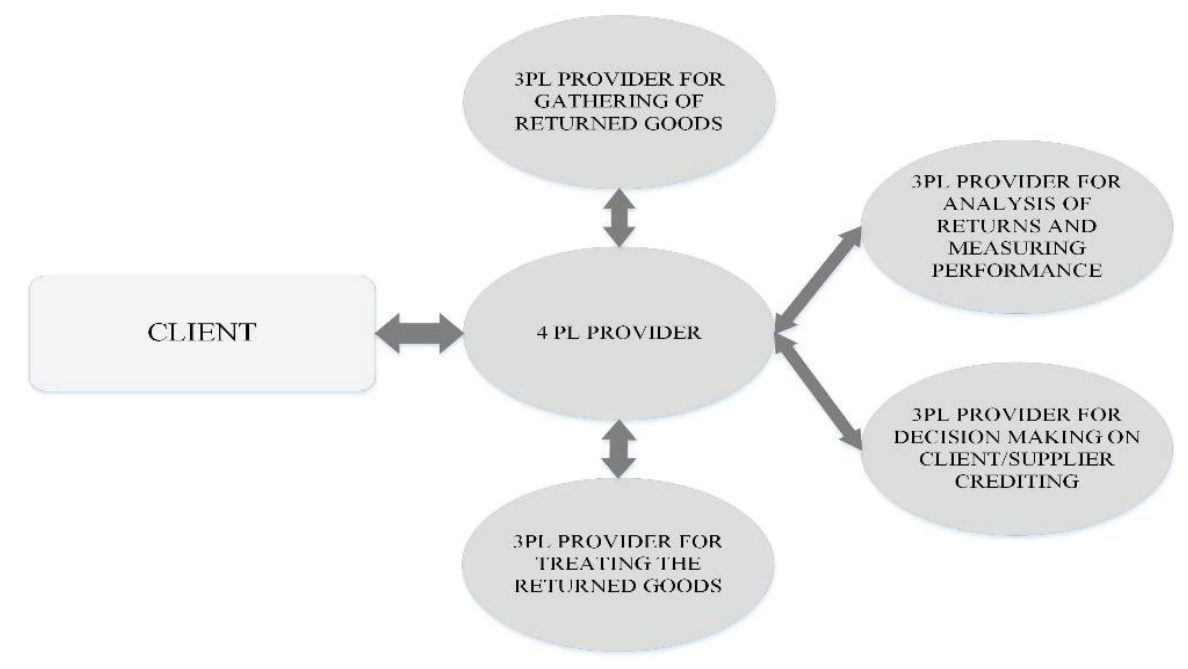

Source: Mukhopadhyay, S., Setaputra, R. (2006), pp. 716-730

Based on the analysis of predicted specifics of the two categories of providers, it can be concluded that 4PL partners have a wider scope of action and a higher level of expertise compared to 3PL providers, both in general logistics operations, and in the case of the realization of the reverse logistics flows. That does not further mean that one partner category excludes the other. On the contrary. While 4PL providers have the leading edge in general management and the organization of the reverse logistics channel, at the same time individual 3PL partners represent experts in the realization of independent activities and process functions, creating in that way a complementary whole. Finally, by passing by the realization of the reverse logistics onto these partner categories, there is a definite segregation of regular and reverse flows, since 3PL and 4PL providers can carry out all the phases of the reverse process independent from the conventional participants within the supply chain. Therefore, their role in the flows of reverse logistics is more than significant and unique. 


\section{THE SECONDARY MARKET PLAYERS}

The secondary market represents a mutual term for a group of wholesalers, retailers, liquidators, brokers and barter companies which sell products that have not been placed through the primary channels of sales for some reason. The companies that do business on the secondary market sell both new, and used, returned goods. It is an often situation in practice that goods be directly placed from the supplier to the secondary market, skipping the other entities within the supply chain. From the analysis performed up to now, it is obvious that these markets are not exclusively connected to the flows of the reverse logistics process. However, since they certainly form an important part of the reverse goods flow, the detailed analysis of several important aspects of the secondary markets enables better understanding of the very reverse logistics, and that is why it is being carried out at this instance. Figure 3 shows certain regular flows and the relations of entities with the secondary market. In order to make a methodological differentiation between the reverse logistics activities and those generally connected with the secondary market, the return activities have been depicted with a dotted line, while the regular activities have been presented by a full line: 


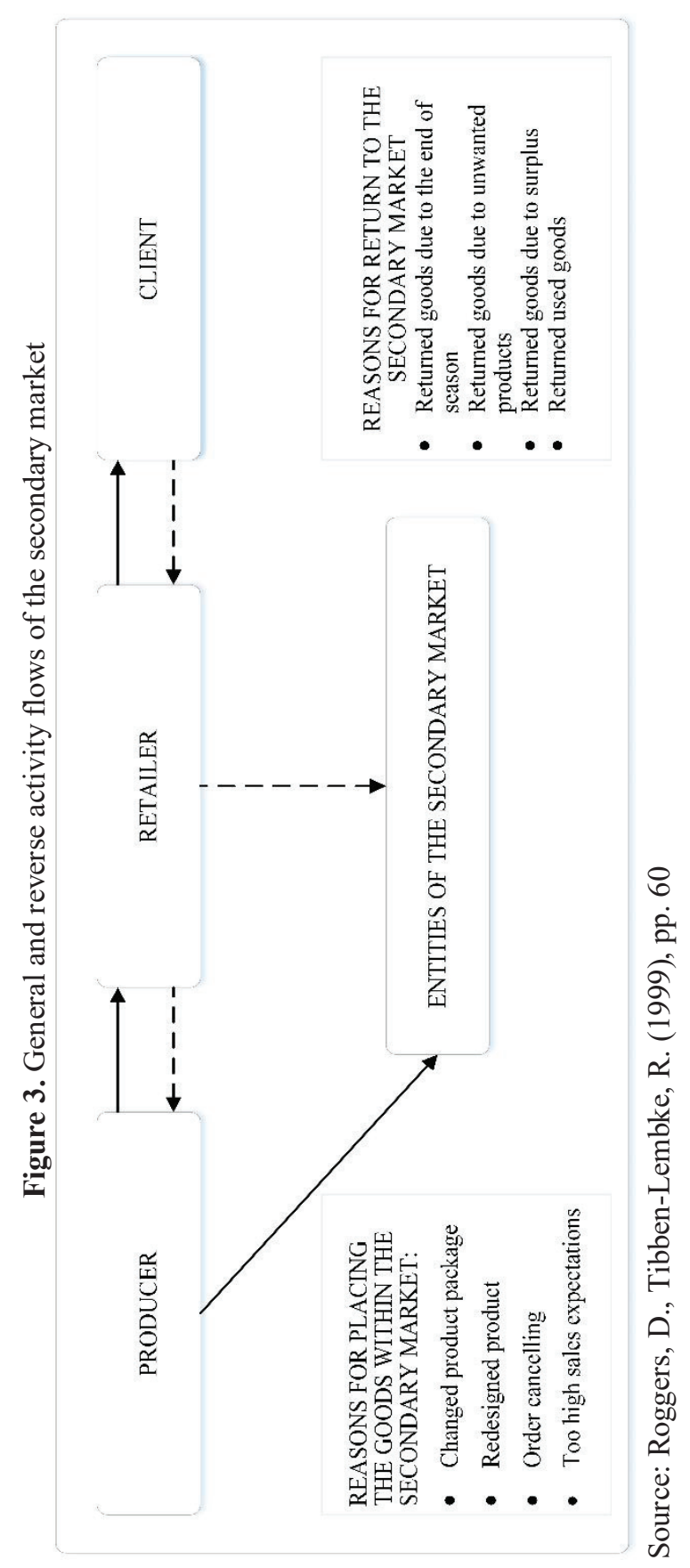


Based on the presented illustration, it is obvious that there are generally four reasons for placing goods onto the secondary market directly by the producer. The first case is connected with the situation where there is a change of product package. The change of product package most often occurs due to the reason that the design is either too old or when the size of the product changes. This especially refers to food or cosmetics products (Fiksel, 1996). Within the second case, the introduction of the new product version speeds up the clearing of the stocks of the old model. Up to the moment of complete sales of the old model, it is most usually sold with a certain discount. If the sales are quickly realized, the product does not need to be placed on the secondary market at all. In case of realization of important changes within the product, the producer can enable the retailer significant incentives in order to sell the remaining products. If bigger modifications are in order, there is a bigger possibility that the product shall surely be placed onto the secondary market (Fiksel, 1996). The cancellation of a greater amount of ordered goods creates significant amounts of stocks and is identified as the third, characteristic case. In those circumstances, the producer is usually ready to sell the mentioned surpluses to any entity which is willing to pay the amount sufficient to cover the costs of product production. Finally, the fourth case refers to the situation where the producer is confronted with solving issues of a greater quantity of piled up, unsold goods created based on wrong, too optimistic sales projections. Instead of keeping on stock a great quantity of goods which need a lot of time to be sold, the producer can decide to pass over the entire quantity to the liquidator, at a lower price. Besides the general costs which refer to the secondary market, the next segment of analysis is connected exclusively to its role within the reverse logistics process, by explaining the activities which specific actors of this market need to realize within it. Namely, the participants of the secondary market secure products for the growing group of retailers, which for example specialize for sales of unwanted returned goods, used products, surplus returns and similar. Since this is a very diversified market, developed exclusively within the developed western economies, it is needed to perform its certain classification. Table 6 shows the main participants of the secondary market with their summed up basic specifics: 
Table 6. Key entities of the secondary market connected to the reverse logistics process and their roles

\begin{tabular}{|c|c|c|c|c|c|}
\hline 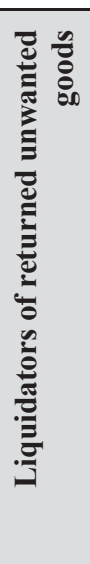 & $\begin{array}{l}\text { They operate with } \\
\text { goods arrived from } \\
\text { the centralized return } \\
\text { centres. They } \\
\text { physically managed } \\
\text { stocks, sort and } \\
\text { consolidate. }\end{array}$ & 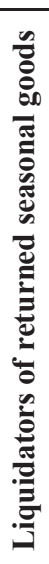 & $\begin{array}{l}\text { They operate with } \\
\text { returns of I class } \\
\text { quality, usually } \\
\text { shoes and clothes. } \\
\text { They negotiate } \\
\text { directly with sales } \\
\text { departments of big } \\
\text { retailers about } \\
\text { procuring goods } \\
\text { which are still on } \\
\text { regular sales. }\end{array}$ & $\begin{array}{l}\frac{0}{0} \\
\frac{\vdots}{0} \\
\frac{0}{0}\end{array}$ & $\begin{array}{l}\text { They operate with } \\
\text { all types of returned } \\
\text { products. They find } \\
\text { clients for the } \\
\text { returned goods, } \\
\text { which they resell } \\
\text { further on. }\end{array}$ \\
\hline 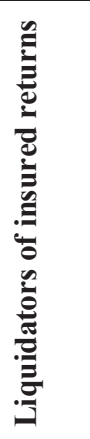 & $\begin{array}{l}\text { They primarily work } \\
\text { with products which } \\
\text { have been declared a } \\
\text { loss in order to } \\
\text { collect the insurance. } \\
\text { They offer the } \\
\text { services and } \\
\text { estimates for supply } \\
\text { losses due to natural } \\
\text { accidents or } \\
\text { disasters. }\end{array}$ & 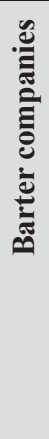 & $\begin{array}{l}\text { They work with the } \\
\text { returned goods } \\
\text { surpluses. } \\
\text { Arrangement are } \\
\text { made in order to } \\
\text { trade with surpluses } \\
\text { of goods of one } \\
\text { company, for the } \\
\text { surpluses of another } \\
\text { company. }\end{array}$ & 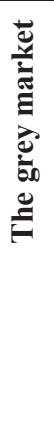 & $\begin{array}{l}\text { They work with } \\
\text { products which do } \\
\text { not have the } \\
\text { company guarantee. } \\
\text { The new products } \\
\text { are sold by re- } \\
\text { sellers unauthorized } \\
\text { by the company. }\end{array}$ \\
\hline
\end{tabular}

Source: Roggers, D., Tibben-Lembke, R. (1999), pp. 92-93

Analysing in detail every of the actors listed within Table 3 several conclusions can be drawn. The liquidators of returned unwanted goods operate on products for there is no more existent demand within retail shelves. Namely, the product may no longer be profitable at the original price, but with its reduction performed by the liquidator, it can become profitable again. These product categories appear due to several reasons: the product is a seasonal good, such as inflatable pools or snow shovels; there is a new, improved version of the product, such is the case with mobile phones; the product has not answered the expectations of the sales department, for example a chips of a certain flavour. Although the goods can be obtained in direct contact with the producer, it is 
mostly delivered via centralized return centres, as a last solution for its disposal. The liquidator delivers further on the goods to flea markets, pond shops, internet stores, processing centres, wastelands etc. The liquidators of returned unwanted goods take into consideration any category of products for which they expect the achievement of a certain profit. It is interesting to mention that the practice has shown that the three most difficult categories to market are: clothes, toys and electronic equipment. The reason for that lies in the specifics of their size (toys), the quick changes of features and characteristics (electronic equipment) as well as expressed seasonal character (when it comes to clothes).

The liquidators of returned seasonal goods usually work with products of I class. However, regarding the structure of goods that are being operated with, it is obvious that it dominantly refers to seasonal returns, and not the products for which there is no expressed demand or a surplus in the process of supply. This category of secondary market participants most often specializes in the returns of clothes and shoes. Consequently, compared to the liquidators of returned unwanted goods, this category has the tendency to focus more narrowly on specific goods, as well as to develop the production expertise and long term relationships with retailers. Another specifics of the liquidators of returned seasonal goods is the unique way in which they gather the given returns. Usually, but not always, these participants negotiate with the sales departments of big retail stores about goods delivery which at that moment is still being sold in retail objects. In this manner, a certain degree of planning the returns in advance is possible. Upon the completed job, the liquidators completely independently organize the returns process, so the goods are finally placed to similar categories, as with the first analysed entity.

Brokers represent a category of the secondary market participants which operates with all types of returned goods (seasonal returns, unwanted goods, surpluses etc.) which are at the end of the life-cycle for any reason. These are entities which are willing to pay symbolic amounts of compensation for the goods which nobody else wants. It is not unusual for brokers to agree arrangements with retailers, where the retailers sell any kind of goods and in any state, of which they have to get rid of, even for the marginal refund. Besides the payback of returns, the brokers usually do not realize the following phases of the returns process, but only resell the goods to other entities (for example the liquidators of returned unwanted goods) who shall decide upon the destiny of the goods.

The liquidators of insured returns are specialized in operating products which have been declared a loss with the purpose to collect the insurance. For example, if there is a car accident in which a truck full of load goes off road, all products contained within it came declared a loss, even in the case that the major part of the delivery has remained intact. In this case, the sender of the goods has two options. The first option is that the transporter who has been engaged for the operation and who is responsible for the accident should pay in full the created loss. In that case, the transporter sells the given goods onto the secondary market to the entity such as the liquidator of insured returns, who buys the content of the truck and further resells it at the most favourable price. If the sender does not wish for the goods to be sold on the secondary market, the other option is to receive a partial compensation for the damaged goods and to return them. In that case, there is no engagement of any participants of the secondary market. 
Barter companies aid other companies to free themselves of surplus products, and in return to gain the desired goods. These actors of the secondary market usually have big warehouses which are accumulated as the result of the previous trade arrangements. The barter companies gain from different participants within the supply chain the undesired supplies of goods in exchange for goods for which these participants estimate to be needed, and is present within the warehouse of the barter company. Usually, the barter companies trade with any category of returns for which they make an estimate that it can be profitable. If a certain return is harder to sell, the exchange of such a product shall be much more complicated. The specifics of some barter companies is that they use universally valuable products, such as airplane tickets, as a unique currency of exchange.

The companies of the grey market sell new products outside of regular flows, usually as re-sellers not approved by production facilities to perform such an activity. The product can be placed onto the grey market in case when a registered re-seller has the need to generate capital, so it decides to discretely sell still new products to the unauthorized reseller for a small profit. The companies of the grey market usually have far lower costs of operations compared to official resellers, so they are able to profitably sell products at far lower prices compared to those suggested to the retailers by the producers. The typical representatives of the grey market are the so-called flea markets. Since such entities are not retailers officially approved by the producers, they have not got its production guarantee. Concluding, it can be stated that even though the companies of the grey market sell dominantly new products, due to the specific way the goods are delivered to these entities, as well as due to the fact that they often represent the final destination for certain used, returned goods, they still have not got a significant role in the reverse logistics process flows.

Based on the analysis of role and engagement of different specific entities of the secondary market, but also other participants of the reverse logistics process, the conclusion is that the organization of such a process is rather complex, so that every participant within it has a particular importance. The degree of complexity of total return flows and the multitude of entities engaged within this process is best depicted within Figure 4. 


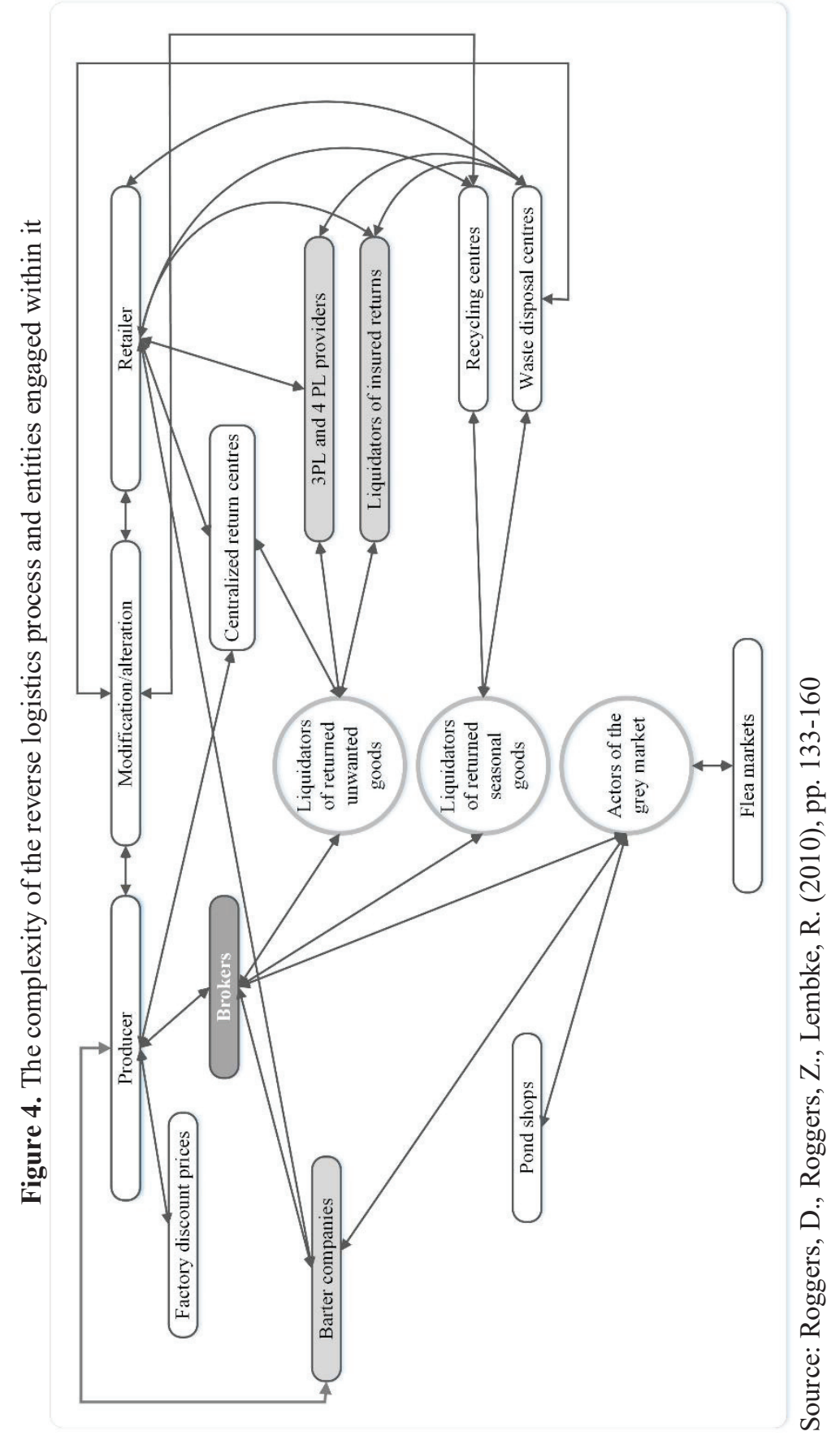




\section{CONCLUSION}

The differentiation of the reverse logistics process can be expressed both by steps out of which the process is comprised of, but also regarding the participants engaged within that process. This differentiation depends on the degree of recognition and practical implementation of the reverse logistics within some industry or within the entire national economy. Namely, all stated analysed entities which have been the main preoccupation of this paper (centralized return centres, 3PL and 4PL providers and secondary market participants) exist within the markets of the developed countries, such as western European countries or USA, where the management of the reverse logistics flows is a reality, i.e. where the importance of this group of activities has a full affirmation within the market competitive battle. Unfortunately, globally seen, there is a much greater participation of those countries where due to insufficient estimate of importance of the reverse logistics flows, the process is not adequately developed, nor the specific entities with their roles and interpersonal relations have been completely differentiated. Thus, the importance of specific entities of the reverse logistics process management on a global scale yet remains to be fully promoted and utilized.

\section{REFERENCES:}

1. Baumgarten, H., Klinkner, R., Sommer-Dittrich, T. (2004), Reconfigurable logistics systems in production of assembly networks. International Journal of Production Research, Vol. 42, No.17, pp. 3647-3655, doi: 10.1080/00207540410001727613

2. Bianchini, A. (2018), 3PL provider selection by AHP and TOPSIS methodology. Benchmarking: An International Journal, Vol. 25, No.1, pp. 235252, https://doi.org/10.1108/BIJ-08-2016-0125

3. Blackburn, J., Guide, D., Souza, G., van Wassenhove, L. (2004), Reverse supply chains for commercial returns. California Management Review, Vol. 46, No. 2 , pp. 6-22, doi: 10.2307/41166207.

4. De Brito, M., Dekker, R. (2004), A framework for reverse logistics. in Dekker, R., Inderfurth, K., van Wassenhove, L., Fleischmann, M. (Eds.) Reverse logistics: quantitative models for closed-loop supply chains, Chapter 1, Springer-Verlag: Berlin.

5. Dowlatshahi, S. (2010), A cost-benefit analysis for the design and the implementation of reverse logistics systems: a case study approach. International Journal of Production Research, Vol. 48, No.5, pp. 1265-1277, doi: 10.1080/00207540802552642.

6. Dudin, M., Voykova, N., Frolova, E., Artemieva, J., Grebennikov, V. (2017), Main Aspects and Directions of an Increase in the Innovative Activity of Logistics Operators. International Review of Management and Marketing, Vol. 6, No.4, pp. 1089-1093. 
7. Dyczkowska, J. (2018), 4PL logistics operator in the supply chain. [available at: http://yadda.icm.edu.pl/yadda/element/bwmeta1.element.baztech-ef6cb240120a-427c-ac27-f7fc448594a6), accessed: 19.02.2019]

8. Fiksel, J. (1996), Design for environment: Creating Eco-efficient Products and Processes, McGraw-Hill, New York, USA.

9. Fleischmann, M., van Wassenhove, L., van Nunnen, J., van der Lann, E., Dekker, R., Bloemhof-Ruwaard, J. (1997), Quantitative models for reverse logistics: a review. European Journal of Operation Research, Vol. 103, pp. 117.

10. Govindan, K., Agarwal, V., Darbari, J. (2019), Environmental management partner selection for reverse supply chain collaboration: a sustainable approach. Journal of environmental management, Vol. 236, pp.784-797, doi: 10.1016/j.jenvman.2018.11.088

11. Govindan, K., Agarwal, V., Darbari, J., Jha, P. (2019), An integrated decision making model for the selection of sustainable forward and reverse logistic providers. Annals of Operations Research, Vol. 273, No. (1-2), pp. 607-650, https://doi.org/10.1007/s10479-017-2654-5

12. Haas, D., Murphy, F., Lancioni, R. (2003), Managing reverse logistic channels with data envelopment analysis. Transportation Journal, Vol. 43, No. 3, pp. 5969.

13. Hall, D., Huscroft, J., Hazen, B., Hanna, J. (2013), Reverse logistics goals, metrics and challenges: perspective from industry. International Journal of Physical Distribution and Logistics Management, Vol. 43, No. 9, pp. 768-785, https://doi.org/10.1108/IJPDLM-02-2012-0052

14. Hertz, S., Alfredsson, M. (2003), Strategic development of third party logistics providers. Industrial Marketing Management, Vol. 32, pp. 139-149.

15. Lai, K. (2004), Service capability and performance of logistics service providers. Transportation Research Part E: Logistics and Transportation Review, Vol. 40 No. 5, pp. 385-399.

16. Meade, L., Sarkis, J. (2002), A conceptual model for selecting and evaluating third-party reverse logistics providers. Supply Chain Management, Vol. 7, No. 5, pp. 283-295.

17. Mukhopadhyay, S., Setaputra, R. (2006), The role of 4PL as the reverse logistics integrator; optimal pricing and return policies. International Journal of Physical Distribution and Logistics Management, Vol. 36, No. 9, pp. 716-730, https://doi.org/10.1108/09600030610710872

18. Paula, I., Campos, E., Pagani, R., Guarnieri, P., Kaviani, M. (2019), Are collaboration and trust sources for innovation in the reverse logistics? Insights from a systematic literature review. Supply Chain Management: An International Journal, https://doi.org/10.1108/SCM-03-2018-0129

19. Perotti, S., Zorzini, M., Cagno, E., Micheli, G. (2012), Green supply chain practices and company performance: the case of 3PLs in Italy. International Journal of Physical Distribution and Logistics Management, Vol. 42, No. 7, pp. 640-672, https://doi.org/10.1108/09600031211258138 
20. Roggers, D., Roggers, Z., Lembke, R. (2010), Creating value through product stewardship and take back, Sustainability, Accounting, Management and Policy Journal, Vol.1, No.2, pp. 133-160.

21. Roggers, D., Tibben-Lembke, R. (1999), Going backwards: reverse logistics trends and practices. Reverse Logistics Executive Council Press: Pittsburgh, USA.

22. Stock, J., Speh, T., Shear, H. (2006). Managing product returns for competitive advantage. MIT Sloan Management Review, Vol. 48, No. 1, pp. 57-62.

23. Trebilcock, B. (2001), Reverse logistics heroes. Modern Materials Handling, Vol. 56, No.10, pp. 63-65.

24. Trebilcock, B. (2002), Third party solutions take charge. Modern Material Handling, Vol. 57, No.11, pp. 33-37.

25. Wiggins, R. (2019). Examination of the Critical Success Factors of a Reverse Logistics Supply Chain (Doctoral dissertation, Capella University). (https://search.proquest.com/openview/d7d0f79fefca5b90b18f1d1440e86799/1 ?pq-origsite $=$ gscholar $\& \mathrm{cbl}=18750 \&$ diss $=\mathrm{y}$ ) 


\title{
ANALIZA TRŽIŠNIH SUDIONIKA KOJI UPRAVLJAJU POVRATNIM LOGISTIČKIM TOKOVIMA I POSLOVNIM OPERACIJAMA
}

\author{
Veljko M. Mijušković27 \& Iva Vuksanović Herceg ${ }^{28}$
}

\begin{abstract}
Sažetak
Prilikom razdvajanja izravnih i povratnih logističkih tijekova uslijed složenosti upravljanja povratnim procesom pojavili su se specifični tržišni sudionici koji su svojstveni jedino za ove tijekove. Uzimajući u obzir organizacijski aspekt ovi entiteti mogu biti formirani od strane sudionika izravnih tijekova, ali mogu biti angažirani i kao specijalizirana eksterna ispomoć. Analize provedene u praksi vezane za ovu tematiku pokazuju da je najveći broj sudionika angažiranih u okviru povratnih logističkih procesa u kategoriji specijaliziranih poslovnih subjekata koji samo obavljaju ovu vrstu posla $i$ koju su neovisni od sudionika regularnih tijekova. Predmet razmatranja u radu je dubinska analiza obujma i značaja povratnih logističkih tijekova fokusirajući se na specifičnosti i tipove entiteta koji su specijalizirani za upravljanje ovim tijekovima, kao što su centralizirani centri za povrat, 3PL i 4PL pružatelji usluga za povratne tijekove kao i različiti poslovni subjekti sekundarnog tržišta. Cilj rada je ukazati na kompleksnost zadataka koje provode specijalizirani subjekti angažirani u okviru povratnog logističkog procesa, na njihovu rijetkost na globalnoj razini te stoga i na ogroman neiskorišten poslovni potencijal koji leži u ovome tržišnom segmentu. To je jedinstvena šansa ne samo za regionalno već i za globalno poslovno okruženje.
\end{abstract}

Ključne riječi: Opseg povratne logistike, značaj povratne logistike, centralizirani centri za povrat, 3PL i 4PL pružatelji usluga, sekundarna tržišta.

JEL klasifikacija: $M 00$

\footnotetext{
${ }^{27}$ Doc.dr.sc. Veljko M. Mijušković, Sveučilište u Beogradu, Ekonomski fakultet, Srbija, E-mail:mijuskovic@ekof.bg.ac.rs

${ }^{28}$ Doc.dr.sc. Iva Vuksanović Herceg, Sveučilište u Beogradu, Ekonomski fakultet, Srbija, E-mail: ivav@ekof.bg.ac.rs
} 